\title{
Paljon sosiaali- ja terveyspalveluja käyttävien asiakkaiden palveluiden toteutuminen - työntekijöiden ja johtavien viranhaltijoiden haastattelututkimus
}

\begin{abstract}
Tutkimuksen tarkoitus oli kuvata, miten paljon palveluja käyttävien asiakkaiden sosiaalija terveydenhuollon palvelut toteutuivat erään peruspalvelukuntayhtymän työntekijöiden ja johtavien viranhaltioiden näkökulmasta. Tutkimuksen tavoitteena oli kehittää paljon palveluja käyttävien asiakkaiden palveluja. Tutkimuksen tiedonantajina $(n=14)$ olivat yksitoista sosiaalija terveydenhuollon ammattilaista ja kolme johtavassa asemassa olevaa henkilöä. Aineisto kerättiiin ryhmäkeskusteluilla $(n=4)$, joissa teemoina olivat Terveyshyötymallin osa-alueet. Keskustelut nauhoitettiïn, litteroitiin ja analysoitiin sisällönanalyysillä.

Asiakkaan omahoitoon sitoutumisen tukeminen koettiin tärkeäksi ja siihen pyrittiin tekemällä yhdessä hoito- ja palvelusuunnitelma. Hoitosuunnitelma koettïn myös tärkeäksi hoitopäätösten tueksi. Tärkeänä päätöksenteon tukena terveydenhuollon työntekijät pitivät lääkärin konsultaatiota ja sosiaalihuollossa lainsäädäntöä. Palveluiden koordinointi ja yhteistyö eri sosiaali- ja terveydenhuollon sektoreiden, myös yksityisten ja kolmannen sektorin kesken, kaipaa kehittämistä. Tietotekniikasta oli hyötyä esimerkiksi hoitopäätöksiä tehtäessä, mutta tietojärjestelmien yhteensopimattomuus ja tietoturva koettiin asiakkaiden palveluiden ja hoidon esteeksi. Paljon palveluja käyttävien asiakkaiden palveluiden koordinoinnissa tulee kehittää palvelunohjausta.
\end{abstract}

\section{Asiasanat: paljon palveluja käyttävä sosiaali- ja terveydenhuollon asiakas, terveyshyötymalli, terveyspalvelut, sosiaalihuolto, hoitosuunnitelma, hoidon koordinointi}

MAIJA ALAHUHTA, EIJA NIEMELÄ

\section{TUTKIMUKSEN LÄHTÖKOHDAT}

Sosiaali- ja terveydenhuollossa keskustellaan asiakkaista, jotka kerryttävät suurimman osan sosiaali- ja terveydenhuollon kustannuksista $(1,2)$. Heitä ovat pitkäaikaissairaat ja muut paljon palveluja käyttävät asiakkaat $(1,3,4)$. Leskelän ym. (1) mukaan $10 \%$ asiakkaista kerryttää $81 \%$ terveyden- ja sosiaalihuollon kokonaiskustannuksista. Näiden kalleimpien asiakkaiden kustannuksista $38 \%$ syntyy terveyspalvelujen käytöstä ja $62 \%$ asiakkailta, jotka käyttävät myös sosiaalipalveluja. Asiakkaista kallein kymmenesosa tarvitsee vuodessa neljää kunnan pal- velukokonaisuutta, muu väestö keskimäärin yhtä. Paljon palveluja käyttävä asiakas määritellään kirjallisuudessa esimerkiksi useiden lääkärin vastaanottokäyntien vuodessa perusteella (5). Kuitenkaan yhtä yleisesti hyväksyttyä määritelmää ei ole $(6,7)$. Tässä tutkimuksessa paljon palveluja käyttävällä asiakkaalla tarkoitetaan vähintään 10 kertaa vuodessa sekä sosiaali- että terveydenhuollon palveluja käyttävää asiakasta (8).

Terveydenhuoltolaissa (9) korostetaan potilaan omaa roolia hoitonsa suunnittelussa, toteutuksessa ja arvioinnissa. Asiakaskeskeisyyden tulee olla palvelujen lähtökohta ja palvelujen 
käyttäjät tulee ottaa mukaan palveluiden kehittämiseen. Asiakkaalla on oikeus valita terveydenhuollon toimintayksikkö, jossa häntä hoidetaan. Tavoitteena on, että palveluiden laatu- ja saatavuustiedot ovat valtakunnanlaajuisesti saatavilla ja auttavat palveluntarjoajan valinnassa. (9)

Pitkäaikaissairaiden hoidossa asiakkaiden tarpeet ja terveydenhuollon palvelujärjestelmät eivät aina kohtaa, koska järjestelmät on aikoinaan luotu akuutteja sairauksia ja tapaturmia varten, jolloin asiakkaan rooli vastaanottotilanteissa on passiivinen. Pitkäaikaissairaiden hoidon organisointi Terveyshyötymallin (Chronic Care Model, CCM) mukaan parantaa pitkäaikaissairauksien hoitoa ja lisää terveyshyötyä $(10,11,12,13)$ sekä vähentää terveydenhuollon kustannuksia $(14,15)$. Mallissa on keskeistä hyvä vuorovaikutussuhde hoitavan tiimin ja asiakkaiden välillä. Terveyshyötymalli muodostuu kuudesta osa-alueesta: omahoidon tuki, palveluvalikoima, päätöksenteon tuki, palveluntuottajan sitoutuminen, tietojärjestelmien tehokas käyttö sekä ympäröivien yhteisöjen tuki $(16,17)$. Terveyshyötymallilla tavoitellaan entistä suunnitelmallisemman ja yksilöllisemmän hoidon järjestämistä pitkäaikaisia sairauksia sairastaville henkilöille (18).

Terveyshyötymallissa keskeistä on varmistaa asiakkaille omahoidon tuki, jotta asiakkaat selviytyvät sairautensa kanssa ja sitoutuvat omahoitoon sekä organisoida tiimityö siten, että potilaiden tarpeisiin pystytään vastaamaan. Asiakkaan oma rooli ja vastuunotto korostuvat. Asiakas on aktiivinen toimija omahoidossaan, joka edellyttää motivaatiota, tietoa, taitoja ja itseluottamusta omaa terveyttä koskevien päätösten tekemiseksi. $(16,17)$ Paljon palveluita käyttävillä asiakkailla on usein monia sairauksia ja erilaisia riippuvuuksia (8), joista voi seurata monia ongelmia asiakkaan terveydentilaan. DiMatteon ym. (19) mukaan huono terveys on yhteydessä hoitoon sitoutumattomuuteen. Zolnierek ja DiMatteon (20) mukaan lääkärin hyvät vuorovaikutustaidot korreloivat potilaiden hoitoon sitoutumiseen. Hoidossa ja palvelusuhteissa tulisikin käyttää ohjausmenetelmiä $(21,22,23)$, jotka edistäisivät hoitoon sitoutumista.

Palveluntuottajan sitoutumisella on erittäin suuri merkitys terveydenhuollon palvelujärjestelmän muuttamisessa ja kehittämisessä. Toimintaa tulee suunnitella siten, että yhteiskunnan voimavarat ja toimintaperiaatteet hyödynnetään mahdollisimman tehokkaasti tekemällä yhteistyötä eri toimijoiden kesken, jolloin myös eri ammattilaisten osaamista voidaan hyödyntää tehokkaasti. Yhteistyö edellyttää kuitenkin asiakkaan palveluvalikoiman suunnittelua ja koordinointia.(15, 18) Vaikka organisaatiot ovat kehittyneet tiimipohjaisiksi ja tiimit toimivat varsin itsenäisesti, niin Isoherrasen (24) mukaan asiakaslähtöisen moniammatillisen yhteistyön soveltaminen käytäntöön on haasteellista. Vanhojen rakenteiden, yhteistyön toimintatapojen ja ammatillisten roolien muuttaminen on vaikeaa. Organisaatiokulttuurin muutos on hidasta, mutta välttämätöntä, koska asiakkaiden ongelmat ovat moninaisia ja tarvitaan monenlaista asiantuntijuutta. (24)

Terveyshyötymallin mukaan $(17,18)$ päätöksenteon tueksi kehitetään ja implementoidaan näyttöön perustuvia hoito-ohjelmia ja arviointityökaluja, jotka tuottavat erilaisia raportteja ja muistutuksia. Myös kouluttautumis- ja konsultaatiomahdollisuudet ovat tärkeitä. Päätöksenteon apuna voidaan käyttää myös esimerkiksi telelääketiedettä ja telekonsultaatiota. Suhtautuminen tietojärjestelmien avulla toteutettavaan päätöksenteon tukeen on osittain ristiriitaista (25). Muistutteet ja herätteet, joiden tarkoitus on esimerkiksi väreillä tai muulla tavoin tuoda esille potilaan tiedoissa normaalista poikkeavia arvoja tai ongelmia, koettiin positiivisina. Erityisesti lääkeinteraktioista annettavat varoitukset nähtiin tarpeellisina. (26) Tarpeettomat tai virheellisiin ja puuttuviin potilastietoihin perustuvat neuvot koettiin haitallisina (27). Ajan tasalla olevien potilastietojen tulee olla rakenteisessa muodossa, jotta järjestelmä pystyy vertaamaan niitä hoitosuositukseen (28).

Terveyden- ja hyvinvoinnin laitos on kehittänyt terveys- ja hoitosuunnitelmalomakkeen, jonka tavoitteena on kehittää erityisesti pitkäaikaisja monisairaiden potilaiden hoitoa ja voimaannuttaa heitä terveydestään huolehtimiseen (29).

Terveyshyötymallin käyttöönoton tavoitteena on parantaa hoidon laatua ja tuloksia sekä hillitä kustannusten nousua käyttämällä resurssit entistä tehokkaammin ja tarkoituksenmukaisemmin (30.) Mallia on hyödynnetty myös muun muassa perusterveydenhuollon kehittämistyön viitekehyksenä (31). 


\section{TUTKIMUKSEN TARKOITUS, TAVOITE JA TEHTÄVÄT}

Tämän tutkimuksen tarkoitus on kuvata paljon palveluja käyttävien asiakkaiden palvelujen toteutumista eräässä sosiaali- ja terveydenhuollon peruspalvelukuntayhtymässä työntekijöiden ja johtavien viranhaltijoiden näkökulmasta. Tutkimuksen tulosten avulla voidaan paljon palveluja käyttävien asiakkaiden palveluja kehittää vastaamaan paremmin asiakkaiden tarpeisiin. Tutkimustehtävien muotoilussa sovelletaan terveyshyötymallin osa-alueita.

Tutkimustehtävät ovat:

1. Millä tavalla paljon palveluja käyttävien asiakkaiden omahoitoon sitoutumista tuetaan sosiaali- ja terveydenhuollossa?

2. Miten sosiaali- ja terveydenhuollossa koordinoidaan paljon palveluja käyttävien asiakkaiden palveluja?

3. Miten yhteistyö toteutuu eri organisaatioiden kesken sosiaali- ja terveydenhuollossa paljon palveluja käyttävien asiakkaiden palveluissa?

4. Millaista päätöksenteon tukea sosiaali- ja terveydenhuollon työntekijöillä on käytettävissä paljon palveluja käyttävien asiakkaiden palveluissa?

5. Miten tietojärjestelmät tukevat paljon palveluja käyttävien asiakkaiden palveluja?

6. Millä tavalla paljon palveluja käyttävien asiakkaiden palveluja tulisi kehittää?

\section{AINEISTO JA MENETELMÄT}

\section{TIEDONANTAJAT}

Tiedonantajien valinta tapahtui siten, että erään peruspalvelukuntayhtymän johtavat viranhaltijat valitsivat työntekijöistään yksitoista tiedonantajaa. Valinnan kriteerinä oli, että tiedonantajilla oli johtavien viranhaltijoiden arvioimana arvokasta kokemusperäistä tietoa paljon palveluita käyttävien asiakkaiden kohtaamisesta. Tiedonantajista neljä oli lääkäriä, neljä sairaanhoitajaa ja kolme sosiaalityöntekijää. Lisäksi tietoja antoi kolme kuntayhtymän johtavaa viranhaltijaa. Tiedonantajina oli yhteensä 14 henkilöä.

\section{AINEISTON KERUU JA ANALYYSI}

Laadullinen aineisto kerättiin keväällä 2015 kolmessa työntekijöiden muodostamassa moni- ammatillisessa ryhmässä ja yhdessä johtavien viranhaltijoiden ryhmässä yhden kuukauden aikana. Työntekijät vastasivat fläppipapereille kirjoitettuihin teemoihin, joita olivat edellä esitetyt tutkimuskysymykset, tiedonkeruun aluksi ensin kukin itsekseen. Kullekin fläppipaperille oli kirjoitettu yksi teema. Tiedonantajat kiersivät fläppipaperilta toiselle siten, että jokainen kirjoitti oman näkemyksensä teemasta paperille. Tähän vaiheeseen kului aikaa noin tunti. Sen jälkeen fläppipaperit jaettiin tiedonantajien kesken siten, että 1-2 henkilöä luki yhden paperin ensin itsekseen läpi ja alleviivasi tai poimi tekstistä keskeiset asiakohdat ja esitti ne muille. Sen jälkeen asioista keskusteltiin yhteisesti. Yhteiskeskustelu nauhoitettiin. Tämä vaihe kesti 1-2 tuntia. Johtavat viranhaltijat haastateltiin omana ryhmänään. Haastattelussa käytettiin samoja teemoja, joita käytettiin työntekijöiden tiedonkeruussa. Haastattelu kesti noin 2 tuntia ja se nauhoitettiin. Tutkimusaineiston muodostivat nauhoitetut haastattelut, jotka litteroitiin sanasta sanaan. Työntekijöiden ja johtavien viranhaltijoiden litteroidut aineistot yhdistettiin. Litteroitua aineistoa saatiin yhteensä 107 sivua (A4), fonttikoko 12.

Aineisto analysoitiin käyttäen laadullista sisällön analyysia. Aluksi aineistoon tutustuttiin lukemalla se useaan kertaan. Analyysiyksiköksi valittiin ajatuskokonaisuus. Litteroitu aineisto jaettiin tutkimustehtävien mukaisiin yhdistäviin luokkiin. Tekstiä pelkistettiin säilyttäen sen keskeinen sisältö. Yhdistävän luokan sisällä samaa tarkoittavat pelkistetyt ilmaisut ryhmiteltiin ja näin syntyneille alaluokille annettiin sisältöä kuvaavat nimet (taulukko 1). Alaluokkia yhdistämällä ja nimeämällä saatiin yläluokat (taulukko 2). (32, 33)

\section{TUTKIMUKSEN TULOKSET}

Tulokset kuvataan tutkimustehtävittäin edeten yhdistävistä luokista ylä- ja alaluokkiin. Yhdistävät luokat ovat omahoitoon sitoutumisen tuki, hoito- ja palvelukokonaisuuden suunnittelu ja koordinointi, yhteistyö organisaatioiden välillä, sosiaali- ja terveydenhuollon työntekijöiden päätöksen teon tuki, tietotekniikka palvelujen tukena ja palvelujen kehittäminen (taulukko 2). 
Taulukko 1. Esimerkki alaluokan muodostumisesta.

\begin{tabular}{|l|l|}
\hline Alaluokka & Pelkistetty ilmaisu \\
\hline Palaverit esimiesten kanssa & Kyllä meillä kans kuuntelee hyvin (esimies), joka tiistai on palaveri. \\
& Kyllä me esimieheltä saadaan semmoista (tukea) \\
& $\begin{array}{l}\text { Ei ollut mikään juoruamiskokous, luottamuksellisesti keskusteltiin ja tehtiin } \\
\text { muistio }\end{array}$ \\
& $\begin{array}{l}\text { Esimiehen tuki on tärkeä, esimiehen neuvot } \\
\text { ja ohjeet, miten tulee toimia (tukea) }\end{array}$ \\
\hline
\end{tabular}

Taulukko 2. Paljon palveluja käyttävien asiakkaiden palveluiden toteutuminen sosiaali- ja terveydenhuollossa peruspalvelukuntayhtymän työntekijöiden ja johtavien viranhaltijoiden näkökulmasta.

\begin{tabular}{|c|c|c|}
\hline Yhdistävät luokat & Yläluokat & Alaluokat \\
\hline \multirow{9}{*}{$\begin{array}{l}\text { Omahoitoon sitoutumisen } \\
\text { tuki }\end{array}$} & \multirow{5}{*}{$\begin{array}{l}\text { Asiakkaan ottaminen mukaan } \\
\text { hoito- ja asiakassuunnitelman } \\
\text { tekemiseen }\end{array}$} & Hoitosuunnitelma sitouttaa asiakkaan \\
\hline & & $\begin{array}{l}\text { Hoitosuunnitelma tehdään yhdessä asiakkaan } \\
\text { kanssa }\end{array}$ \\
\hline & & Asiakassuunnitelman avulla osallistetaan \\
\hline & & $\begin{array}{l}\text { Hoidon- ja palvelutarpeen arviointi yhdessä } \\
\text { asiakkaan kanssa }\end{array}$ \\
\hline & & Asiakkaan kokonaistilanteen huomiointi \\
\hline & \multirow{4}{*}{$\begin{array}{l}\text { Toimintatapa keskusteleva ja } \\
\text { asiakaslähtöinen }\end{array}$} & Oma tekeminen \\
\hline & & Itsestä vastuun ottaminen \\
\hline & & Asiakkaan omat päätökset \\
\hline & & Omasta elämästä puhuminen \\
\hline \multirow{17}{*}{$\begin{array}{l}\text { Hoito- ja palvelukokonai- } \\
\text { suuden suunnittelu ja } \\
\text { koordinointi }\end{array}$} & \multirow{4}{*}{$\begin{array}{l}\text { Suunnittelun ja } \\
\text { koordinoinnin tavoite ja tarve }\end{array}$} & Päällekkäisten palveluiden karsiminen \\
\hline & & Asiantuntijoiden osaamisen hyödyntäminen \\
\hline & & Asiakkaat hakevat palveluita useasta eri paikasta \\
\hline & & Asiakkaan palvelut ovat hajallaan \\
\hline & \multirow{3}{*}{$\begin{array}{l}\text { Kaikki koordinoivat omalta } \\
\text { osaltaan }\end{array}$} & Jokainen ammattilainen koordinoi itse \\
\hline & & Asiakas koordinoi itse \\
\hline & & Omainen koordinoi \\
\hline & \multirow[t]{2}{*}{$\begin{array}{l}\text { Lait toiminnan järjestämisen } \\
\text { perustana }\end{array}$} & $\begin{array}{l}\text { Lastensuojelussa lain mukaan sosiaalityöntekijä } \\
\text { koordinoi }\end{array}$ \\
\hline & & $\begin{array}{l}\text { Kotihoidossa lakisääteinen hoito- ja } \\
\text { palvelusuunnitelma }\end{array}$ \\
\hline & \multirow{3}{*}{$\begin{array}{l}\text { Palvelukokonaisuutta ei } \\
\text { koordinoi kukaan asiakkaan } \\
\text { näkökulmasta }\end{array}$} & Ei ole palveluketjun ohjaajaa \\
\hline & & Kukaan ei koordinoi kokonaisuuden näkökulmasta \\
\hline & & $\begin{array}{l}\text { Koordinointi ei ulotu sekä sosiaali- että } \\
\text { terveydenhuollon puolelle }\end{array}$ \\
\hline & \multirow{3}{*}{$\begin{array}{l}\text { Tiedon kulkuun liittyvät } \\
\text { koordinoinnin haasteet }\end{array}$} & Tieto ei välity sosiaali- ja terveydenhuollon välillä \\
\hline & & $\begin{array}{l}\text { Tietosuoja estää tiedon kulkemisen ilman asiakkaan } \\
\text { lupaa tai osallistumista }\end{array}$ \\
\hline & & Tietojärjestelmien yhteensopimattomuus \\
\hline & \multirow[t]{2}{*}{$\begin{array}{l}\text { Koordinoinnin onnistumisen } \\
\text { edellytykset }\end{array}$} & $\begin{array}{l}\text { Asiakkaan suostumus tietojen käyttöön } \\
\text { edellytyksenä koordinoitiin }\end{array}$ \\
\hline & & $\begin{array}{l}\text { Hyvä yhteistyö eri osapuolten kesken edellytyksenä } \\
\text { koordinointiin }\end{array}$ \\
\hline
\end{tabular}




\begin{tabular}{|c|c|c|}
\hline \multirow[t]{5}{*}{$\begin{array}{l}\text { Yhteistyö organisaatioiden } \\
\text { välillä }\end{array}$} & $\begin{array}{l}\text { Moniammatillisen yhteistyön } \\
\text { tarve ja hyöty }\end{array}$ & $\begin{array}{l}\text { Asiakkaiden tarpeet monimutkaisia } \\
\text { Yhden ammattiryhmän tiedot ja taidot eivät riitä } \\
\text { Jokaisen osaamista voidaan hyödyntää }\end{array}$ \\
\hline & $\begin{array}{l}\text { Yhteisesti laaditut } \\
\text { tavoitteet sitouttavat } \\
\text { moniammatilliseen } \\
\text { yhteistyöhön } \\
\end{array}$ & $\begin{array}{l}\text { Yhteisesti laaditut tavoitteet } \\
\text { Yhteisiin tavoitteisiin sitoutuminen }\end{array}$ \\
\hline & $\begin{array}{l}\text { Sosiaali- ja terveydenhuollon } \\
\text { välinen yhteistyö }\end{array}$ & $\begin{array}{l}\text { Yhteistyötä ei tehdä } \\
\text { Yhteistyötä tehdään työyksiköiden sisällä } \\
\text { Yhteistyötä ei ole eri sektoreiden välillä } \\
\text { Yhteistyötä on kuitenkin esim. lastensuojelussa, } \\
\text { mielenterveys- ja päihdepalveluissa } \\
\text { Tietosuoja on yhteistyön esteenä } \\
\text { Yhteistyökumppaneita ei tunneta eikä toisten } \\
\text { työnkuvaa tunnisteta }\end{array}$ \\
\hline & $\begin{array}{l}\text { Yksityisten palveluntuottajien } \\
\text { ja sosiaali- ja } \\
\text { terveydenhuollon välinen } \\
\text { yhteistyö }\end{array}$ & $\begin{array}{l}\text { Sosiaalihuollossa yhteistyötä tehdään perhetyössä, } \\
\text { terapiapalveluissa, lastensuojelussa } \\
\text { Ostopalveluja käytetään siivouspalveluissa ja } \\
\text { palveluasumisessa } \\
\text { Palvelujen kehittäminen } \\
\text { Terveydenhuollossa ostetaan tutkimuksia ja } \\
\text { konsultaatiota } \\
\text { Yhteistyön positiiviset puolet } \\
\text { Yhteistyön haasteet }\end{array}$ \\
\hline & $\begin{array}{l}\text { Kolmannen sektorin ja } \\
\text { sosiaali- ja terveydenhuollon } \\
\text { välinen yhteistyö }\end{array}$ & $\begin{array}{l}\text { Yhteistyötä vähän kolmannen sektorin ja sosiaali- } \\
\text { ja terveydenhuollon välillä } \\
\text { Yhteistyötä potilasjärjestöjen ja MML:n kanssa } \\
\text { Kolmannen sektorin palveluista ohjataan hakemaan } \\
\text { vertaistukea } \\
\text { Yhteistyön esteet kolmannen sektorin ja sosiaali- } \\
\text { ja terveydenhuollon välillä }\end{array}$ \\
\hline \multirow[t]{6}{*}{$\begin{array}{l}\text { Sosiaali- ja } \\
\text { terveydenhuollon } \\
\text { työntekijöiden } \\
\text { päätöksenteon tuki }\end{array}$} & $\begin{array}{l}\text { Asiakkaasta saatava tieto } \\
\text { päätöksenteon perustana }\end{array}$ & $\begin{array}{l}\text { Keskustelut/haastattelut asiakkaan kanssa } \\
\text { Asiakkaan havainnointi } \\
\text { Hoitosuunnitelman tekeminen asiakkaan kanssa }\end{array}$ \\
\hline & $\begin{array}{l}\text { Konsultaatiot päätöksenteon } \\
\text { tukena }\end{array}$ & $\begin{array}{l}\text { Lääkäri selustan turvaaja ja auktoriteetti } \\
\text { Lääkärin tekemät erikoislääkärin konsultaatiot } \\
\text { Hoitajien väliset konsultaatiot } \\
\text { Sosiaali- ja terveydenhuollon väliset konsultaatiot }\end{array}$ \\
\hline & $\begin{array}{l}\text { Palaverit päätöksenteon } \\
\text { tukena }\end{array}$ & $\begin{array}{l}\text { Sosiaali- ja terveydenhuollon väliset palaverit } \\
\text { Kollegojen väliset palaverit } \\
\text { Palaverit esimiesten kanssa }\end{array}$ \\
\hline & $\begin{array}{l}\text { Työntekijän ammattitaito } \\
\text { auttaa päätöksenteossa }\end{array}$ & $\begin{array}{l}\text { Työntekijän jämäkkyys } \\
\text { Työntekijän työkokemus } \\
\text { Työntekijän koulutus } \\
\end{array}$ \\
\hline & $\begin{array}{l}\text { Ohjeistukset ja kirjallisuus } \\
\text { päätöksenteon tukena }\end{array}$ & $\begin{array}{l}\text { Käypä hoito suositukset } \\
\text { Työpaikan ohjeet, erilaiset testit ja mittarit }\end{array}$ \\
\hline & $\begin{array}{l}\text { Lainsäädäntö päätöksenteon } \\
\text { perustana }\end{array}$ & $\begin{array}{l}\text { Sosiaali- ja terveydenhuollon lait ja asetukset } \\
\text { STM suositukset }\end{array}$ \\
\hline
\end{tabular}




\begin{tabular}{|c|c|c|}
\hline \multirow[t]{2}{*}{$\begin{array}{l}\text { Tietotekniikka } \\
\text { palvelujen tukena }\end{array}$} & Tietotekniikan ongelmat & $\begin{array}{l}\text { Tietojärjestelmien yhteensopimattomuus ja kalleus } \\
\text { Tietosuoja ja tietoturva yhteistyön esteenä } \\
\text { Tilastoinnin hyödyntäminen vaikeaa }\end{array}$ \\
\hline & Tietotekniikan hyödyt & $\begin{array}{l}\text { Internetin terveystieto käytössä } \\
\text { Sosiaalinen media mahdollisuutena } \\
\text { Tiedolla johtaminen tavoitteena } \\
\text { Toiminnan vaikuttavuuden mittareiden käyttö esim. } \\
\text { RAI-toimintakykymittari }\end{array}$ \\
\hline \multirow[t]{4}{*}{$\begin{array}{l}\text { Palvelujen } \\
\text { kehittäminen }\end{array}$} & $\begin{array}{l}\text { Tietotekniikan ja sähköisten } \\
\text { palveluiden kehittäminen }\end{array}$ & $\begin{array}{l}\text { Sähköisen omahoitojärjestelmän kehittäminen } \\
\text { Tietotekniikan ja tietosuojan kehittäminen } \\
\text { Yhteisen ajanvarausjärjestelmän kehittäminen }\end{array}$ \\
\hline & $\begin{array}{l}\text { Resurssit ja asenteet esteenä } \\
\text { palveluiden kehittämiselle }\end{array}$ & $\begin{array}{l}\text { Aikaa ja resursseja liian vähän } \\
\text { Työntekijän asenne vaikuttaa palveluun }\end{array}$ \\
\hline & Yhteistyön kehittäminen & $\begin{array}{l}\text { Yhteistyön kehittäminen yli sektorirajojen } \\
\text { Yhteistyön kehittäminen yksityisten } \\
\text { palveluntuottajien kanssa } \\
\text { Monipuolinen viranomaisyhteistyö } \\
\text { Verkostopalaverit } \\
\text { Asiakkaiden perheenjäsenten mukaan ottaminen } \\
\text { yhteistyöhön }\end{array}$ \\
\hline & $\begin{array}{l}\text { Palveluohjauksen } \\
\text { kehittäminen }\end{array}$ & $\begin{array}{l}\text { Palvelujen koordinointiin suunnitelmallisuutta } \\
\text { Suunnittelusta ja koordinoinnista vastaavan } \\
\text { työntekijän käyttöönotto }\end{array}$ \\
\hline
\end{tabular}

\section{OMAHOITOON SITOUTUMISEN TUKI}

Paljon palveluja käyttävien asiakkaiden omahoitoon sitoutumista tuettiin ottamalla asiakkaat mahdollisimman paljon mukaan hoitosuunnitelman tekemiseen terveydenhuollossa ja asiakassuunnitelman laatimiseen ja tarkistamiseen sosiaalipalveluissa. "Asiakasta pyritään osallistamaan ja laaditaan yhdessä asiakassuunnitelma." Asiakkaan kokonaistilanne pyrittiin huomioimaan. Toimintapa oli keskusteleva ja asiakaslähtöinen, jota kuvattiin asiakkaan omana tekemisenä ja itsestä vastuun ottamisena, asiakkaan omien päätösten ja omasta elämästä puhumisen tukemisena.

\section{HOITO- JA PALVELUKOKONAISUUDEN SUUNNITTELU JA KOORDINOINTI}

Paljon palveluita käyttävien asiakkaiden palvelukokonaisuuden suunnittelun ja koordinoinnin tavoite oli päällekkäisten palveluiden karsiminen ja henkilöstön osaamisen hyödyntäminen. Palveluiden koordinointi on tarpeen, koska paljon palveluita käyttävä asiakas on usein sekä sosiaaliettä terveydenhuollon palveluita käyttävä esimerkiksi niin sanotut somatisoijat hakevat palveluita useasta eri paikasta.
Palvelukokonaisuuden suunnittelua ja koordinointia tekivät kaikki omalta osaltaan, mutta palveluiden koordinointia ei tee kukaan asiakkaan kokonaistilanteen näkökulmasta. Sosiaalihuollossa palveluja koordinoi sosiaalityöntekijä, terveydenhuollossa se henkilö, jonka potilaana asiakas pääasiallisesti on. Koordinoinnin katsottiin kuuluvan asiakkaalle itselleen, omaiselle, omahoitajalle ja jokaiselle ammattilaiselle. "Monestihan aktivoidaan kyllä asiakasta, että teidän täytyy varata aika. Mutta voidaan vaikka perheneuvolaan soittaa ja varata aika asiakkaalle. Poikkeustapauksessa." Kotihoidossa tehtiin lakisääteinen hoito- ja palvelusuunnitelma, jota arvioitiin kaksi kertaa vuodessa. Mielenterveyspuolella palvelu- ja hoitosuunnitelman teki ylilääkäri.

Tiedon asiakkuudesta olisi hyvä olla sekä sosiaali- että terveydenhuollon työntekijöillä. Asiakkaat eivät välttämättä myöskään halua palveluita, esimerkiksi mielenterveyspalveluja, vaikka se olisi työntekijän mielestä tarpeen. Koordinoinnin haasteena koettiin informaation kulku, tietojärjestelmät ja tietosuoja. Koordinoinnin onnistumisessa on tärkeää asiakkaan suostumus ja yhteistyö. 


\section{YHTEISTYÖ ORGANISAATIOIDEN VÄLILLÄ}

Moniammatillista yhteistyötä pidettiin tarpeellisena, koska asiakkaiden tarpeet ovat monimutkaisia ja yhden ammattiryhmän tiedot ja taidot eivät riitä vastaamaan niihin. Yhteistyön hyötyinä nähtiin se, että jokaisen osaamista voidaan hyödyntää asiakkaan parhaaksi. Alkuvaiheessa tarvitaan lääkäriä tekemään diagnooseja ja linjaamaan hoitoratkaisuja. Myöhemmin lääkärin rooli voi olla konsultti, kun sekä asiakas että hoitotiimi ovat sitoutuneet yhdessä laadittuihin tavoitteisiin.

Sosiaali- ja terveydenhuollon välistä yhteistyötä sekä tehtiin, että ei tehty. Sosiaali- ja terveydenhuollon välillä koettiin olevan raja-aidan, joka esti yhteistyön tekemisen. Yhteistyötä tehtiin kuitenkin yli raja-aidan sosiaalipalveluissa esimerkiksi neuvolan ja lastensuojelun kesken sekä mielenterveys- ja päihdepalveluissa. Yhteistyötä oli työyksiköiden sisällä ja se muotoutui työyksikön mukaan. Yhteistyön esteenä koettiin olevan tietosuojan sekä sen, että ei tunnistettu toisen sektorin työtä ja osaamista. "Pitää tietää mitä laki sanoo mistäkin asiasta, että minkä tiedon voi välittää ja mitä voi kysyä jostakin.”

Yksityisten palveluntuottajien kanssa yhteistyötä oli sosiaalihuollossa; perhetyössä, terapiapalveluissa ja lastensuojelussa. Lisäksi ostettiin yksityisten palveluntuottajien siivous- ja palveluasumispalveluja. Palveluja kehitettiin myös yhteistyössä, esimerkiksi lastensuojelulla ja perhekodilla oli kehittämiskumppanuus. Ennaltaehkäisevän työn puolella oli mahdollisuus käyttää yksityisten palveluntuottajien palveluita. Sosiaalipuolella koettiin, että yksityisten yritysten palvelutarjonta vastaa hyvin asiakkaiden tarpeisiin ja odotuksiin. Terveydenhuollossa yksityisiä palveluntuottajia käytettiin lähinnä tutkimuksiin ja konsultaatioihin sekä ohjattiin potilaita hakemaan sairauslomaa ja todistuksia silloin, kun julkisen puolen aikoja ei ollut saatavilla. Yksityisten palveluntuottajien toivottiin erikoistuvan joidenkin palveluiden tarjoamiseen. Koettiin, ettei ollut luotettava palveluntarjoaja, jos tarjosi kaikkea mahdollista palvelua. Toisaalta useita palveluja tarjoava yritys koettiin joustavana. ”Nehän ovat asiakkaalle tosi joustavia palveluntuottajia, kun ne siivoavat ja leipovat ja tekevät mitä käsketään, kun kotihoito keskittyy nykyään enempi hoitamiseen." Yritys tekee tällöin kaiken, mitä asiakas tarvitsee. Hyvänä pidettiin myös sitä, että yksityiset palveluntuottajat tarjoavat palveluja myös iltaisin ja viikonloppuisin. Yhteistyön haasteena julkisen ja yksityisten palveluntuottajien välillä oli se, että julkisen puolen toimijat eivät tienneet yksityisistä palveluista, eivätkä osanneet niitä asiakkailleen ehdottaa. Yksityisen palveluntuottajien palvelut koettiin tarpeellisina, mutta kontrollin pitää säilyä julkisen puolen toimijoilla, koska vastuu palvelujen järjestämisestä on kuitenkin julkisella puolella, vaikka palvelun tarjoaa yksityinen taho. Yksityisiä palveluja asiakas osti suoraan itse tai hän sai palvelusetelin tai maksusitoumuksen.

Yhteistyötä kolmannen sektorin kanssa oli vähän, lähinnä potilasjärjestöjen ja Mannerheimin lastensuojeluliiton kanssa. Asiakkaita ohjattiin hakemaan vertaistukea kolmannen sektorin tarjoamista palveluista. Lisäksi käytiin luennoimassa kolmannen sektorin järjestämissä tilaisuuksissa ja heiltä saatiin lahjoituksia. Yhteistyötä voitaisiin tehdä myös seurakunnan ja eläkejärjestöjen kanssa. Tiedon puute kolmannen sektorin toiminnasta oli eräs yhteistyön este.

\section{SOSIAALI- JA TERVEYDENHUOLLON TYÖNTEKIJÖIDEN PÄÄTÖKSENTEON TUKI}

Sosiaali- ja terveydenhuollon työntekijöiden päätöksenteko perustui asiakkaiden kanssa keskusteluun ja asiakkaiden havainnointiin. Hoitosuunnitelma oli tärkeä tuki hoitopäätöksiä tehtäessä. Tärkeänä päätöksenteon tukena terveydenhuollon työntekijät pitivät konsultaatioita. Lääkäri koettiin selustan turvaajana ja auktoriteettina. Lääkäreiden keskinäiset konsultaatiomahdollisuudet koettiin hyviksi, myös erikoislääkärin konsultaatioihin potilas oli mahdollista lähettää melko vapaasti. Sekä sisäisiä että toimialojen välisiä ja hoitaja-hoitaja konsultaatiomalleja kehitettiin.

Palaverit omien kollegoiden ja esimiehen kanssa olivat tärkeitä päätöksenteossa. Lisäksi ammattitaito auttoi päätöksenteossa. Ammattitaidoksi kuvattiin jämäkkyyttä, työkokemusta ja koulutusta. Päätöksenteon tukena käytettiin myös kirjallisuutta ja ohjeistuksia, esimerkiksi Käypähoito -suosituksia, työyksikön omia ohjeistuksia esimerkiksi triage-luokitusta päivystyspotilaiden hoidon tarpeen arvioinnissa sekä valmiita testejä ja arviointimittareita. Sosiaali- 
ja terveydenhuollon lainsäädäntö ohjaa päätöksentekoa, etenkin sosiaalihuollon palveluiden saamisen perustana on usein laki tai asetus.

\section{TIETOTEKNIIKKA PALVELUJEN TUKENA}

Tietotekniikan käytön ongelmana oli eri tietojärjestelmien yhteensopimattomuus ja kalleus. Myös tietosuoja ja salassapitovelvollisuus koettiin potilastyössä yhteistyön, tiedonsaannin ja tiedonvälityksen esteeksi tai haitaksi. Lääkäreille oli annettu tietojärjestelmässä laajimmat oikeudet asiakkaan eri tietoihin. Yleensä asiakkaat antoivat työntekijälle luvan omien tietojensa katsomiseen, jos sitä heiltä kysyttiin. Jos potilas kielsi pääsyn johonkin tiedostoon, niin järjestelmässä on vaikeaa tehdä rajaus ja estää pääsy tiedostoihin yksittäisen asiakkaan kohdalla. Monenlaista tilastointia tehtiin päivittäin jokaisen asiakkaan jälkeen. Tilastoitujen tietojen esiin saamisessa tietojärjestelmistä oli kuitenkin ongelmia tai niitä ei vielä osattu hyödyntää.

Asiakkaat voivat hyötyä internetistä löytyvästä terveystiedosta, Facebook - ryhmistä tai sosiaalisesta mediasta, mutta paljon palveluja käyttävät asiakkaat usein haluavat käydä lääkärin ja tuttujen työntekijöiden luona.

Johtavien viranhaltijoiden tavoitteena oli johtaa tiedolla. Perinteisiä mittareita seurattiin, esimerkiksi käyntimääriä, mutta vaikuttavuusmittareita oli huonosti käytössä. RAI -toimintakykymittaristo oli otettu käyttöön, jolloin esimies pystyy tarkastelemaan asiakkaiden toimintakyvyn muutoksia työntekijäkohtaisesti.

\section{PALVELUJEN KEHITTÄMINEN}

Tietotekniikan ja sähköisten palveluiden kehittäminen koettiin tärkeäksi. Omahoidon tukeen on kehitetty sähköistä omahoitojärjestelmää. Tietotekniikkaa ja tietosuojaa tulee kehittää siten, että ne eivät ole esteenä asiakkaiden palvelujen koordinoinnille. Kaivattiin ajanvaraussysteemiä, jonka avulla olisi helposti varattavissa yhteinen aika kaikille asiakkaan hoitoon ja tukemiseen osallistuville.

Resurssit ja asenteet kuvattiin esteiksi palvelujen kehittämiselle. Ei ole tarpeeksi aikaa asiakkaiden asioihin paneutumiseen. Kuitenkin paljon palveluja käyttävät asiakkaat käyttivät työntekijöiden aikaa runsaasti. Tiedostettiin, että jos asiakkaalla olisi tiedossa seuraava vastaanottoaika, joka olisi tarpeeksi pitkä, hän todennäköisesti käyttäisi vähemmän päivystyspalveluja. Seurantakäyntien välillä asiakas voisi tulla autetuksi pelkällä puhelinkontaktilla esimerkiksi sairaanhoitajaan, kun hän tietäisi, että hänen asiansa on jonkun hallinnassa. "Antamalla potilaalle aikaa, säästetään aikaa.” Tämä ei kuitenkaan nykyisellään toteudu. Jokaisen työntekijän omalla asenteella on merkitystä palveluun. Työntekijä pääsee helpommalla, kun hän tekee asiakkaan puolesta kaikki tai menee sen taakse, että ei löydy aikaa tai toimii vain omalla luukulla: "ei tää kuulu meille, menkääpä katteleen munalta”.

Yhteistyön kehittäminen nähtiin tärkeänä. Pidettiin tärkeänä kehittää edelleen sosiaali- ja terveydenhuollon sektorirajat ylittävää ja yksityisten palveluntuottajien kanssa tehtävää yhteistyötä. Lisäksi haluttiin kehittää monipuolista viranomaisyhteistyötä, pitää verkostopalavereja ja ottaa asiakkaan perheenjäseniä mukaan neuvonpitoon.

Palveluiden koordinointiin toivottiin suunnitelmallisuutta. Paljon palveluja käyttävän asiakkaan pitää saada palveluohjausta, mutta hänen kohdallaan pitää myös varmistaa, että hän siirtyy palveluihin. Ratkaisuksi ehdotettiin palvelukoordinaattoria, jolla on aikaa paneutua asiakkaan kokonaistilanteeseen.

\section{POHDINTA}

\section{TULOSTEN TARKASTELU}

Paljon palveluita käyttävien asiakkaiden palveluissa työntekijät korostivat asiakkaan omahoitoa ja vastuun ottamista omasta elämästään. Omahoidon onnistumisen edellytys on asiakkaan hoitoon sitoutuminen. Kaattarin ym. (34) mukaan tulee terveydenhuollon toimintayksiköissä kiinnittää huomiota asiakkaiden selviytymistaitojen tukemiseen sekä itsenäisessä päätöksenteossa että sosiaalisten verkostojen luomisessa.

Palvelukokonaisuuden suunnittelun ja koordinoinnin todettiin olevan tärkeää sekä potilaan hyvän hoidon ja palvelun että yhteiskunnan näkökulmasta. Asiakasvastaava-malli tarjoaa mahdollisuuden työnjaon kehittämiseksi monisairaiden ja paljon palveluja tarvitsevien asiakkaiden hoidon varmistamiseksi. Asiakasvastaava-mallissa terveyden- tai sosiaalihuollon ammattilainen 
vastaa hoitosuunnitelman mukaisesti asiakkaidensa omahoidon tukemisesta, hoidon toteutuksesta ja koordinoinnista. Asiakasta ei lähestytä sairaus kerrallaan, vaan kohtaamisessa otetaan huomioon koko ihminen erilaisine tarpeineen ja ongelmineen. $(15,35$.)

Yhteistyön tekeminen eri terveyden- ja sosiaalihuollon palvelusektoreiden välillä koettiin tärkeänä, koska asiakkaat käyttävät molempia palveluja. Työntekijät eivät tiedä, mitä kaikkia palveluja asiakas käyttää, eivätkä tunne toisten ammattiryhmien työtä. Isoherrasen (24) mukaan moniammatillisen yhteistyön haasteita ovat joustavista rooleista sopiminen, vastuukysymysten määrittely, yhteisen tiedon luomisen käytännöt sekä moniammatillisessa yhteistyössä tarvittavien vuorovaikutus- ja tiimityötaitojen oppiminen. Lisäksi haasteena koetaan organisaation rakenteet, jotka eivät aina mahdollista yhteisen tiedon luontia, jaettua johtajuutta ja tiimin oman toimintamallin yhdessä arviointia ja kehittämistä. Moniammatillisesti hyvin toimivissa tiimeissä asiantuntijat luottavat toisiinsa ja tukevat toisiaan. Tällaisissa tiimeissä halutaan työskennellä, niissä kehittyy sosiaalista pääomaa, joka auttaa myös kaikkien ammattiryhmien edustajien työssä jaksamista.

Hoitosuunnitelma koettiin tärkeänä päätöksenteon tukena. Terveyden- ja hyvinvoinnin laitos on kehittänyt terveys- ja hoitosuunnitelmalomakkeen, jonka tavoitteena on kehittää erityisesti pitkäaikais- ja monisairaiden potilaiden hoitoa ja voimaannuttaa heitä omasta terveydestään huolehtimiseen. (29). Sote-tieto hyötykäyttöön 2020-strategia (36) linjaa, että paljon palveluita käyttävän asiakkaan kanssa laaditaan kansallisesti hyödynnettävä, yhteinen ja moniammatillinen asiakaskohtainen kokonaissuunnitelma, joka integroi mahdolliset organisaatio- ja sektorikohtaiset suunnitelmat. Kokonaissuunnitelma mahdollistaa asiakkaan palveluiden ja palvelukokonaisuuden ohjaamisen ja suunnitelman toteutumisen seurannan sekä sen yhdistämisen palveluntuottajien toiminnanohjaukseen (36).

Käypä hoito -suositusten koettiin tässä tutkimuksessa auttavan päätöksentekoa. Miettisen ja Korhosen (25) mukaan Käypä hoito -suosituksia käytetään päätöksenteon tukena ja eräänlaisena laaduntarkkailun välineenä sekä muistin tukena tai taustatukena ja omien tietojen päivittämisessä.
Terveyden- ja sosiaalihuollon työntekijät kokivat tietotekniikan ja tietosuojan olevan esteenä asiakkaiden hoidolle ja palvelujen järjestämiselle sekä moniammatilliselle yhteistyölle. Toisaalta Isoherrasen (24) mukaan tietotekniikan kehittyminen mahdollistaa tarvittavan tiedon liikkumisen ja kokoamisen yhteen yli asiantuntija- ja organisaatiorajojen.

\section{LUOTETTAVUUDEN POHDINTA}

Laadullisen tutkimuksen luotettavuuden kriteereitä ovat uskottavuus, siirrettävyys, luotettavuus ja todeksi vahvistettavuus (37). Tutkimustulosten uskottavuus perustuu tiedonantajien tuottamaan monipuoliseen aineistoon. Tiedonantajiksi pyrittiin saamaan henkilöitä, joilla oli kokemusta paljon palveluita käyttävien asiakkaiden palvelujen toteutumisesta ja kykyä tuottaa siitä tietoa. Ryhmähaastattelut olivat ilmapiiriltään luottamuksellisia. Fläppipapereihin tuotetuilla kirjallisilla teksteillä pyrittiin varmistamaan, että kaikkien osallistujien mielipiteet saatiin kuuluville. Moniammatillinen ryhmä tuotti asiasta monipuolista tietoa ja rikkaan aineiston. Ryhmähaastatteluissa oli useita teemoja. Vähemmillä teemoilla olisi voinut saada syvällisempää tietoa. Aineiston analyysin luotettavuutta on pyritty lisäämään käyttämällä kahta luokittelijaa, jotka ovat yhdessä päätyneet esitettyihin tuloksiin. Tulokset kuvaavat erään peruspalvelukuntayhtymän työntekijöiden käsityksiä paljon palveluja käyttävien asiakkaiden palveluiden toteutumista. Tutkimustulosten siirrettävyyden arviointia auttaa tutkimukseen osallistuneiden henkilöiden ja tutkimusprosessin tarkka raportointi. Suoria lainauksia on käytetty osoittamaan yhteyttä alkuperäiseen aineistoon. Tulosten todeksi vahvistettavuutta on pyritty lisäämään keskustelemalla niistä eri yhteyksissä johtavien viranhaltijoiden kanssa. Luotettavuutta olisi lisännyt myös muiden tiedonantajien arviointi tuloksista.

\section{EETTISYYS}

Tutkimuslupa sosiaali- ja terveydenhuollon toimijoiden haastatteluun pyydettiin kuntayhtymän johtavilta viranhaltijoilta. Osallistuminen ryhmähaastattelutilanteeseen tulkittiin suostumukseksi osallistua tutkimukseen. Aineistonkeruun aluksi informoitiin tutkimuksesta ja siihen osallistumisen vapaaehtoisuudesta. Suoria lainauksia käytettiin vain vähän, jotta tiedonantajien henkilöl- 
lisyys ei paljastuisi, koska tiedonantajien määrä oli melko vähäinen. Tutkijat olivat organisaation ulkopuolisia henkilöitä ja osallistuivat ryhmiin tehden tarkentavia kysymyksiä haastattelujen ja keskustelujen aikana. He pyrkivät olemaan vaikuttamatta tiedonantajien käsityksiin ja mielipiteisiin.

\section{PÄ̈̈TELMÄT}

Paljon palveluja käyttävien asiakkaiden sosiaalija terveydenhuollon palveluissa tarvitaan selkeämpää koordinointia, jotta palvelut vastaavat asiakkaiden tarpeisiin. Koordinointi auttaa siten, että asiakkaiden tarpeet ja henkilökunnan osaaminen kohtaavat. Yhteistyötä eri sektoreiden kesken tulee lisätä, koska paljon palveluita käyttävät asiakkaat käyttävät sekä terveyden- että sosiaalihuollon palveluja. Tietojärjestelmät tulee saada tukemaan paremmin sekä asiakkaiden että henkilökunnan tarpeita.

Tutkimuksen tavoitteena oli kehittää paljon palveluja käyttävien asiakkaiden palveluja, siksi ehdotamme, että
- paljon palveluja käyttävien asiakkaiden palveluiden koordinointia parannetaan asiakaskohtaisella kokonaissuunnitelmalla ja palveluohjauksella.

- sosiaali- ja terveydenhuollon sekä yksityisten palveluntuottajien yhteistyötä kehitetään. Tavoitteena ovat asiakaslähtöiset palvelut.

- tietojärjestelmiä ja tietotekniikkaa kehitetään ja hyödynnetään edelleen siten, että ne mahdollistavat entistä paremmin sosiaali- ja terveydenhuollon yhteistyön (yhteiset tietojärjestelmät) ja tukevat väestön omahoitoa esimerkiksi siten, että ohjaus, omaseuranta ja vastaanottotoiminta mahdollistuvat netissä ja mobiililaitteilla.

\section{KIRJOITTAJIEN KONTRIBUUTIOT}

MA osallistui sekä tutkimuksen suunnitteluun, toteutukseen että artikkelin kirjoittamiseen. EN osallistui tutkimuksen suunnitteluun, toteutukseen ja artikkelin kirjoittamiseen.

\section{Alahuhta M, Niemelä E. The realization of services of frequent attenders in health and social care - an interview study of the employees and the leading officeholders. Sosiaalilääktieteellinen aikakauslehti - Journal of Social Medicine 2017:54: 6-17}

The purpose of the research was to describe how the services of frequent attenders were realized in health and social care from the employee's point of view. The results of the research help us to develop the services of frequent attenders in order to meet their needs better. The informants (14) in the study were eleven professional working in primary health care and social services and their superiors $(n=3)$. The qualitative research data was gathered by group interviews $(n=4)$. The themes of the interviews were from the Chronic Care Model. The discussions were recorded, transcribed and analyzed by using content analysis.

The support of customers' self-care was considered important and it can be reached by doing a care and service plan together. The care plan was considered important in supporting decision making about care. Health care employees found doctor's consultation one of the most important forms of support in decision-making. Legislation often supports decision-making in social care. The coordination and co-operation of services between different health and social care sectors, private and third sectors, need to be developed. Information technology was useful for example in making care decisions, but incompatibility of information systems and information security were considered obstacles of customers' services and care.

The coordination of health and social care services is the most important challenge when developing public health and social care services.

Keywords: Frequent Attender in Social and Health Care, The Chronic Care Model, Health Services, Social Welfare, Patient Care Planning, Case Management 
(1) Leskelä R-L, Komssi V, Sandström S, ym. Paljon sosiaali- ja terveyspalveluja käyttävät asukkaat Oulussa. Suomen lääkärilehti 2013;48:31633169.

(2) Kapiainen S, Väisänen A, Haula T. Terveydenhuollon yksikkökustannukset Suomessa vuonna 2011. Tampere: Juvenes Print, Terveyden- ja hyvinvoinnin laitos; 2014.

(3) Smits F, Brouwer HJ, ter Riet G, ym. Epidemiology of frequent attenders: a 3-year historic cohort study comparing attendance, morbidity and prescriptions of one-year and persistent frequent attenders. Public Health 2009;9:36.

(4) Kivelä K. Kuvaus paljon terveyspalveluita käyttävien ikäihmisten terveyspalveluiden käytöstä. Oulun kaupunki; 2014. Luettu 28.10.2015.

https://www.innokyla.fi/documents/990395/ ede5507e-6b7e-4939-a072-b8a3e832e78d

(5) Jyväsjärvi S. Frequent attenders in primary health care. A cross-sectional study of frequent attenders psychosocial anf family factors, chronic diseases and reasons for encounter in a finnish health centre. Acta Universitatis Ouluensis, Series D, Medica (639). Oulu. Oulun yliopisto; 2001. Luettu 12.11.2014. http://herkules.oulu.fi/isbn9514264460/

(6) Doupe MB, Palatnick W, Day S, ym. Frequent users of emergency departments: developing standard definions and defining prominent risk factors. Ann Emerg Med 2012; 60:24-32.

(7) Koskela T-H. Terveyspalveluiden pitkäaikaisen suurkäyttäjän ennustekijät. Kuopion yliopiston julkaisuja D, Lääketiede 425; 2008. Luettu 23.4.2015.

http://wanda.uef.fi/uku-vaitokset/ vaitokset/2008/isbn978-951-27-0945-8.pdf

(8) Savilampi J, Sumukari M. Paljon palveluja käyttävän asiakkaan kokemuksia sosiaalija terveydenhuollon palveluista. Oulun ammattikorkeakoulu; 2015. Luettu 27.5.2016. http://www.theseus.fi/bitstream/ handle/ 10024/95133/Sumukari_Minna.pdf?sequence=1

(9) Terveydenhuoltolaki 2010/ 1326. http://www.finlex.fi/fi/laki/ajantasa/2010/ 20101326

(10) Vedsted P, Christensen MB. Frequent attenders in general practice care: a literature review with special reference to methodological considerations. Public Health 2005;119:118137.

(11) Stellefsson M, Dipnarine K, Stopka C. The Chronic Care Model and Diabetes Management in US Primary Care Settings: A systematic Review. Prev Chronic Dis 2013;10(E26)

(12) Cramm JM, Nieboer AP. Short and long term improvements in quality of chronic care delivery predict program sustainbility. Soc Sci Med 2014;101:148-154
(13) Halladay J, DeWalt D, Wise A, ym. More extensive Implementation of the Chronic Care Model is Associated with Better Lipid Control in Diabetes. J Am Board Fam Pract 2014;27: 34-41.

(14) Hariharan, J, Tarima S, Azam L, ym. Chronic Care Model as a Framework to Improve Diabetes Care at an Academic Internal Medicine Faculty-Resident Practice. J Ambul Care Manage 2014;37: 42-50.

(15) Wagner EH, Sandhu N, Newton KM, ym. "Effect of Improved Glycemic Control on Health Care Costs and Utilization”. JAMA 2001;285:182-189.

(16) Goetzel RZ, Ozminkovski RJ, Villagra VG, ym. "Return on Investment in Disease Management: A Review," Health Care Financing Review 2005;26:1-19

(17) Wagner EH, Austin BT, Davis C, ym. Improving Chronic Illness Care: Translating Evidence into Action. Health Aff 2001;20:64-78.

(18) Wagner EH. Chronic Disease Management: What Will It Take To Improve Care for Chronic Illness? Effective Clinical Practice 1998;1:2-4. Luettu 27.2.2014. www.acponline.org/clinical_information/ journals_publications/ecp/augsep98/cdm.pdf

(19) DiMatteo MR, Haskard KB, Williams SL. Health beliefs, disease severity, and patient adherence: a meta-analysis. Medical Care 2007;45:521-8.

(20) Zolnierek KB, DiMatteo MR. Physician communication and patient adherence to treatment: a meta-analysis. Medical Care 2009;47:826-34.

(21) Barbarat S, Stalder SF.. Therapeutic patient education in atopic eczema. Br J Dermatol 2014;170:44-48.

(22) Halloran PDO', Blackstock F, Shields N, ym. Motivational interviewing to increase physical activity in people with chronic health conditions: a systematic review and metaanalysis. Clin Rehabil 2014;28:1159-1171.

(23) Lagger G, Pataky Z, Golay A. Efficacy of therapeutic patient education in chronic diseases and obesity. Patient Educ Couns 2010;79:283286.

(24) Isoherranen K. Uhka vai mahdollisuus moniammatillista yhteistyötä kehittämässä._ Helsingin yliopisto, valtiotieteellinen tiedekunta, sosiaalitieteiden laitos, sosiaalipsykologia; 2014. Luettu 12.12.2015. URN:ISBN:978-952-10-7664-0

(25) Miettinen M, Korhonen M. Käypä hoito -suositukset ja päätöksenteon tuki terveydenhuollon prosesseissa. Tapaustutkimus Käypä hoito -suositusten käytöstä ja terveydenhuollon ammattilaisten näkemyksistä päätöksenteon tuesta. Savoniaammattikorkeakoulu; 2005. 
(26) Jousimaa J. The Clinical use of Computerized Primary Care Guidelines. Kuopio. Kuopion yliopisto. Kuopion yliopiston julkaisuja D. Lääketiede 250; 2001.

(27) Kortteisto T. Neuvova potilaskertomus. Käyttö ja vaikutus potilaan hoitoon. Tampere. Acta Universitatis Tamperensis 1905. Suomen yliopistopaino Oy. Juvenes Print; 2014.

(28) Kunnamo I, Jousimaa J. Tietoverkot ja sähköinen maailma hoitosuositusten toteuttamisessa. Duodecim Aikakauskirja 2004;120:2977-84.

(29) Komulainen J, Vuokko R, Mäkelä M. Rakenteinen terveys- ja hoitosuunnitelma. Tampere. Terveyden- ja hyvinvoinnin laitos; 2011. Luettu 12.9.2014. www.julkari.fi/ bitstream/handle/10024/80180/890688ae-578c4ab0-aada-1d16c3a7f79f.pdf? sequence $=1$

(30) STM. Sosiaalisesti kestävä Suomi 2020. Sosiaali- ja terveyspolitiikan strategia. 2010. Luettu 25.5.2015. http:// www.stm.fi/c/document_library/get file? folderId=39503\&name=DLFE-14357.pdf

(31) PPSHP. Hyvä Potku -hanke. 2015. Luettu 27.2.2015. https://www.ppshp.fi/pth/ kehittaminen/hyvapotku

(32) Kankkunen P, Vehviläinen-Julkunen K. Tutkimus hoitotieteessä. Helsinki. WSOYpro Oy; 2009.

(33) Graneheim UH, Lundman B. Qualitative content analysis in nursing research: concepts, procedures and measures to achieve trustworthiness. Nurse Educ Today 2004;24:105-112.

(34) Kaattari A, Tiirinki H, Turkki L, ym. Perusterveydenhuollon palveluiden suurkäyttäjä Pohjois-Suomen syntymäkohorttiaineistossa. Sosiaalilääketieteellinen aikakauslehti 2015;52:191-201.

(35) Kanste O, Holappa M, Miettinen K, ym. Monisairaille oma palveluohjaaja terveysasemalta - kohti hyvää elämää. Kirjassa: Muurinen S, Nenonen M, Wilksman K, ym. Uusi terveydenhuolto. Hoitotyön vuosikirja 2010. Helsinki. Fioca Oy. 2010.

(36) STM, Kuntaliitto Tieto hyvinvoinnin ja uudistuvien palveluiden tukena. Sote-tieto hyötykäyttöön -strategia 2020. 2015. Luettu 1.2.2015. www.stm.fi/c/document_library/get file?folderId=39503\&name=DLFE-33103.pdf.

(37) Lincoln YS, Cuba EG. Naturalistic Inquiry. NewburyPark, CA. Saga Publications; 1985.

Majja Alahuhta

TtT, Lehtori

Oulun ammattikorkeakoulu $\mathrm{O} y$

Eija NiEMElä

TtT, Yliopettaja

Oulun ammattikorkeakoulu $\mathrm{Oy}$ 